\title{
Multiplex PCR for identification of two butterfly sister species: Eurema mandarina and Eurema hecabe
}

\author{
Mai N. Miyata ${ }^{1}$, Daisuke Kageyama ${ }^{2^{*}}$ (1) and Masashi Nomura ${ }^{1^{*}}$
}

\begin{abstract}
Objective: In insects, closely related species are often difficult or impossible to distinguish solely by morphological traits. Mitochondrial DNA (mtDNA) markers are often useful and reliable for distinguishing closely related species. However, useful mtDNA markers can be unavailable, particularly when such species pairs experienced hybrid introgression in the past. Although polymorphic nuclear DNA markers would be necessary to distinguish such species pairs, recombination, multiple copies, and slower mutation rates of the nuclear DNA compared with those of mtDNA often make it challenging. The objective of this study was to develop a multiplex polymerase chain reaction that can reliably amplify and distinguish the Tpi sequences of Eurema mandarina and Eurema hecabe.

Results: We successfully analyzed the nucleotide sequences of the $Z$ chromosome-linked triose phosphate isomerase (Tpi) gene to develop a multiplex polymerase chain reaction (PCR) that amplified ca. 120-bp products for E. mandarina and ca. 375-bp products for E. hecabe. We suggest that multiplex PCR using Tpi with appropriately designed primers can be used to accurately and reliably distinguish between other closely related Lepidoptera species.
\end{abstract}

Keywords: Eurema mandarina, Eurema hecabe, Eurema blanda, Multiplex PCR

\section{Introduction}

Insects are the most abundant and diverse group of living organisms on this planet [1]. Some congeneric insect species, which were once considered to be the same species, have later be divided into distinct species based on detailed morphological characters or nucleotide sequences [2]. Mitochondrial DNA (mtDNA), such as cytochrome c oxidase subunit I (COI), is often used as a molecular marker to distinguish closely related species [3-5]. However, mtDNA markers cannot be used for species identification when closely related species have experienced hybrid introgression with each other in the past [6-10]. Although polymorphic nuclear DNA markers are

\footnotetext{
*Correspondence: kagymad@affrc.go.jp; nomuram@faculty.chiba-u.jp ${ }^{1}$ Graduate School of Horticulture, Chiba University, Matsudo, Chiba 271-8510, Japan

2 Institute of Agrobiological Sciences, National Agriculture and Food Research Organization, 1-2 Owashi, Tsukuba, Ibaraki 305-0851, Japan
}

necessary to distinguish such species [11], it is sometimes challenging to design appropriate primers for nuclear DNA because of the possibility of recombination and multiple copies.

Here, we focused on two sister species of butterfly: Eurema mandarina and Eurema hecabe (Lepidoptera; Pieridae). These species are very difficult to distinguish morphologically, and they were considered as a single species, E. hecabe, for a long time [12]. However, Kato and Handa (1992) found that temperate populations and subtropical populations of $E$. hecabe differed in their expression of polyphenism in response to photoperiod and temperature [13]. Following this discovery, it was found that the two types of $E$. hecabe were distinct in a number of traits, such as their host plants [14], wing fringe color [15], reflection pattern against ultra-violet rays [16], allelic frequencies of allozymes [17], and nuclear DNA sequences [18]. These data consistently and

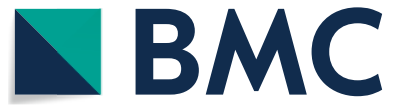

(c) The Author(s) 2020. This article is licensed under a Creative Commons Attribution 4.0 International License, which permits use, sharing, adaptation, distribution and reproduction in any medium or format, as long as you give appropriate credit to the original author(s) and the source, provide a link to the Creative Commons licence, and indicate if changes were made. The images or other third party material in this article are included in the article's Creative Commons licence, unless indicated otherwise in a credit line to the material. If material is not included in the article's Creative Commons licence and your intended use is not permitted by statutory regulation or exceeds the permitted use, you will need to obtain permission directly from the copyright holder. To view a copy of this licence, visit http://creativeco mmons.org/licenses/by/4.0/. The Creative Commons Public Domain Dedication waiver (http://creativecommons.org/publicdomain/ zero/1.0/) applies to the data made available in this article, unless otherwise stated in a credit line to the data. 
strongly suggest that the temperate populations with a yellowish wing fringe ( $\mathrm{Y}$ type) and the subtropical populations with a brownish wing fringe (B type) constitute closely related but distinct biological species, E. mandarina and $E$. hecabe, respectively [19, 20]. Therefore, $E$. mandarina and E. hecabe are a good model system to investigate the evolutionary aspects of closely related species, such as their speciation process, adaptation to local environments, and biogeographical history [18, 21].

In both E. mandarina and E. hecabe, a single strain of Wolbachia endosymbiont, which causes cytoplasmic incompatibility and is referred to as $w \mathrm{CI}$, is fixed in most of the populations of these two congeneric species. Based on molecular phylogenetic analyses, it has been suggested that the two species experienced hybrid introgression quite recently in the evolutionary timeframe: cytoplasm of $E$. hecabe was considered to have moved to E. mandarina together with $w \mathrm{CI}$, and then $w \mathrm{CI}$-occurring cytoplasm experienced a selective sweep within and across populations through the effect of cytoplasmic incompatibility [18]. Similar events of hybrid introgression have also been reported for other species [22, 23]. Therefore, E. mandarina and E. hecabe cannot be distinguished using mtDNA [24].

According to Narita et al. (2006), nucleotide sequences of the $\mathrm{Z}$ chromosome-linked triose phosphate isomerase (Tpi) gene were distinct between E. mandarina and E. hecabe [18]. To avoid the complications of cloning and sequencing of the Tpi sequences, we developed a multiplex polymerase chain reaction (PCR) that reliably amplifies species-specific sequences of $T p i$ from $E$. mandarina and $E$. hecabe. This method allows easy and unambiguous identification of the two butterflies.

\section{Main text}

Materials and methods

\section{Sample collection and morphological identification}

The collection sites and number of Eurema individuals used in this study are listed in Table 1 (see Additional file 1 for details). We sampled 29 female and 38 male $E$. hecabe from 4 populations and 22 female and 16 male $E$. mandarina from 14 populations which were difficult to distinguish by morphological observation. Additionally, we sampled 6 females from 1 population of E. blanda, which is a species that is diverged from $E$. hecabe and $E$. mandarina. Wild-caught $E$. hecabe and E. mandarina were brought into the laboratory and carefully inspected under a dissecting microscope for morphological species identification using wing fringe color and cell spots on the underside of the forewing [25]. E. blanda specimens were easily identified by the black shape on a section of their forewings, shape of their hindwing, and three cell spots on the underside of their forewing [12], and they
Table 1 Collection sites of the butterflies used in this study

\begin{tabular}{|c|c|c|}
\hline Species & Location & $\begin{array}{l}\text { No. } \\
\text { of examined } \\
\text { individuals }\end{array}$ \\
\hline \multirow[t]{4}{*}{ Eurema hecabe } & Okinawa Is., Okinawa & $8(8 f)$ \\
\hline & Ishigaki Is., Okinawa & $8(8 f)$ \\
\hline & Yonaguni Is., Okinawa & $47(9 f, 38 m)$ \\
\hline & Taiwan & $4(4 f)$ \\
\hline \multirow[t]{14}{*}{ Eurema mandarina } & Morioka, Iwate & $3(3 f)$ \\
\hline & Minamiuonuma, Nigata & $2(1 \mathrm{f}, 1 \mathrm{~m})$ \\
\hline & Mashiko, Tochigi & $1(1 f)$ \\
\hline & Karuizawa, Nagano & $3(1 f, 2 m)$ \\
\hline & Tsukuba, Ibaraki & $3(2 f, 1 m)$ \\
\hline & Chichibu, Saitama & $3(3 m)$ \\
\hline & Matsudo, Chiba & $3(3 f)$ \\
\hline & Kimitsu, Chiba & $1(1 \mathrm{f})$ \\
\hline & Fujiyoshida, Yamanashi & $3(1 \mathrm{f}, 2 \mathrm{~m})$ \\
\hline & Hokuto, Yamanashi & $3(1 \mathrm{f}, 2 \mathrm{~m})$ \\
\hline & Shimanto, Kochi & $3(1 f, 2 m)$ \\
\hline & Himeshima Is., Oita & $3(3 m)$ \\
\hline & Tanegashima Is., Kagoshima & $5(5 f)$ \\
\hline & Okinawa Is., Okinawa & $2(2 f)$ \\
\hline Eurema blanda & Ishigaki Is., Okinawa & $6(6 f)$ \\
\hline
\end{tabular}

Numbers of females and males are in parentheses ( $f$ : females, $m$ : males)

are morphologically distinct from E. mandarina and $E$. hecabe. After morphological species identification, all the samples were stored at $-30^{\circ} \mathrm{C}$ until DNA extraction.

\section{DNA extraction}

A DNeasy Blood \& Tissue Kit (QIAGEN, Tokyo, Japan) was used to extract DNA from all samples. From each individual butterfly, ca. $50 \mathrm{mg}$ thoracic muscles were squashed using a plastic pestle in a $1.5-\mathrm{ml}$ microcentrifuge tube containing $180 \mu \mathrm{l}$ of buffer AL and $20 \mu \mathrm{l}$ of proteinase $\mathrm{K}$ solution. Following incubation at $56{ }^{\circ} \mathrm{C}$ for $2 \mathrm{~h}$, DNA was extracted following standard protocols. For the final step, $150 \mu \mathrm{l}$ of buffer AE was used to elute the DNA from each sample.

\section{Development of species-specific $P C R$ primer pairs}

$T p i$ sequences containing a highly variable intron, which were amplified by using the primers [26] in our previous studies ([21] and LC468358-LC468414), were subjected to multiple alignment by using the software MEGA 7 [27]. The aligned sequences were subjected to PrimerBLAST software [28] to design species-specific primers for E. mandarina and E. hecabe, respectively. According to in silico analyses, the primer pairs Em4-F and Em4-R amplifies ca. 120-bp products of $E$ mandarina, and the primer pairs Eh6-F and Eh6-R amplifies ca. 375-bp 
products of $E$. hecabe (Table 2). These primer pairs were not considered to amplify any products from E. blanda. All of these primers were synthesized by FASMAC Co., Ltd. (Kanagawa, Japan).

\section{PCR methods}

The PCR reaction mixtures consisted of $0.5 \mu \mathrm{l}$ of genomic DNA solution, $1 \mu \mathrm{l}$ of dNTP Mixture, $1 \mu \mathrm{l}$ of $10 \times$ PCR buffer, $0.5 \mu \mathrm{l}$ of each primer, $0.05 \mu \mathrm{l}$ of Takara Ex Taq (Takara Shuzo Co., Ltd., Kyoto, Japan), and X $\mu$ l distilled water, where $\mathrm{X}$ was 5.45 for multiplex PCR and 6.45 for singleplex PCR. The PCR condition was $94.0^{\circ} \mathrm{C}$ for $5 \mathrm{~min}$, followed by 35 cycles of $94.0^{\circ} \mathrm{C}$ for $30 \mathrm{~s}, 48^{\circ} \mathrm{C}$ for $30 \mathrm{~s}, 72.0^{\circ} \mathrm{C}$ for $30 \mathrm{~s}$, and finally $72.0^{\circ} \mathrm{C}$ for $7 \mathrm{~min}$. The universal Tpi primers [26] were used as an internal positive control and distilled water was used as a negative control. The PCR products were separated using $2 \%$ agarose gel electrophoresis containing 0.01\% GelRed (Wako Pure Chemical Industries, Ltd., Osaka, Japan).

\section{Results and discussion}

As expected, a singleplex PCR using the primer pair Em4-F and Em4-R consistently amplified ca. 120-bp products from $E$. mandarina $(\mathrm{n}=38)$ but no products from $E$. hecabe $(\mathrm{n}=67)$ (Table 2). However, a singleplex PCR using the primer pair Eh6-F and Eh6-R consistently amplified ca. 375 -bp products from E. hecabe $(\mathrm{n}=67)$ but no products from E. mandarina $(\mathrm{n}=38)$ (Table 2). These primer sets did not amplify any products from $E$. blanda $(\mathrm{n}=6)$. Collectively, both primer pairs appeared to be suitable for species identification among E. hecabe, E. mandarina, and E. blanda.

When we performed a multiplex PCR assay including both primer pairs, Em4-F/Em4-R and Eh6-F/Eh6-R, in a PCR reaction we successfully amplified a single product of ca. $120 \mathrm{bp}$ in size from $E$. mandarina $(\mathrm{n}=38)$, a single product of ca. $375 \mathrm{bp}$ in size from E. hecabe $(\mathrm{n}=67)$, and no products from E. blanda $(\mathrm{n}=6)$ (Fig. 1). Therefore, this multiplex PCR assay allows us to easily distinguish the three butterflies using a single PCR reaction.

Table 2 Sequences of Tpi primers used in this study

\begin{tabular}{lll}
\hline Primer & Sequence & Target species \\
\hline Em4-F & 5'-GGCTCCAACAATTGGGAGATTA-3' & Eurema mandarina \\
Em4-R & 5'-TACAGGCAATGACCTTGAGGC-3' & This study \\
Eh6-F & 5'-TGTGGCCTTCTGCCCTATTAAA-3' & Eurema hecabe \\
Eh6-R & 5'-ACAGGCAATGACCTTGAGTC-3' & This study \\
Tpi-F & 5'-GGTCACTCTGAAAGGAGAACCACTTT-3' Universal (Lepidoptera) \\
Tpi-R & 5'-CACAACATTTGCCCAGTTGTTGCAA-3' & \\
\hline
\end{tabular}

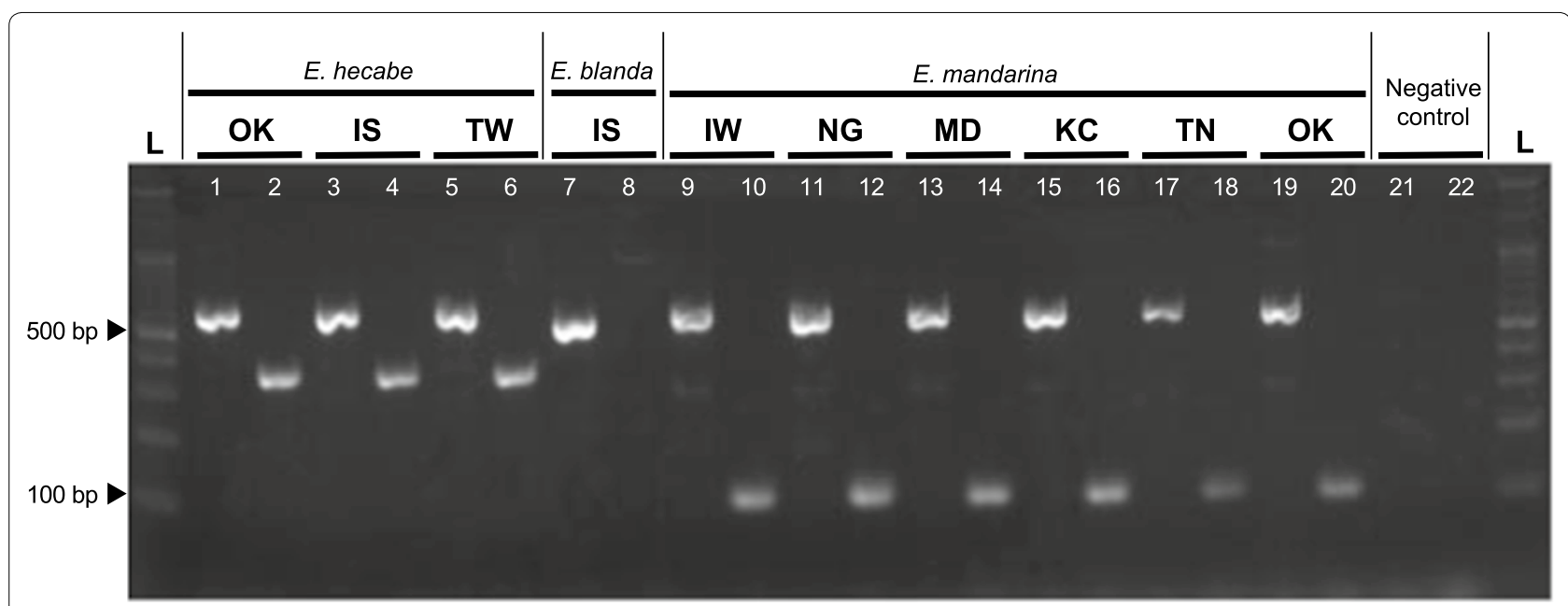

Fig. 1 Species-specific amplification using multiplex PCR. Lanes with odd numbers are those amplified using a universal Tpi primer set (Tpi-F/Tpi-R) and lanes with even numbers are those amplified using multiplex Tpi primer sets (Em4-F/Em4-R and Eh6-F/Eh6-R). Lanes 1-6 are E. hecabe, lanes 7-8 are E. blanda, lanes 9-20 are E. mandarina, and lanes 21-22 are a negative control. L: 100-bp ladder. OK: Okinawa Island, IS: Ishigaki Island, TW: Taiwan, IW: Iwate, NG: Nigata, MD: Matsudo, KC: Kochi, TN: Tanegashima Island 
By the advent of high-throughput sequencing, sequencing is becoming accessible to massive amounts of nucleotide sequence data, which provides reliable grounds for the taxonomic classification of different species, as well as phylogenetic inferences on different taxa [11]. However, when it comes to simple and easy methods to distinguish closely related species, multiplex PCR is still the most appropriate approach in many cases. In some cases, PCR could be substituted with loop-mediated isothermal amplification, which is easier to conduct but more difficult to design primers for [29].

In the present study, we established a multiplex PCR that can distinguish E. mandarina and E. hecabe easily, reliably, and cost-effectively. We consider that, at least in Lepidoptera, Tpi gene sequences are moderately variable. They are variable enough to differentiate different species but invariable enough to allow designing primers within species. Therefore, Tpi is a potential target for marker development of multiplex PCR to distinguish other closely related lepidopteran species when other approaches, such as mtDNA, are unavailable. Along with other nuclear genes, the Tpi gene is also useful for constructing a higher-level phylogeny of insects [30].

\section{Limitations}

We mainly used E. mandarina and E. hecabe that were collected in Japan. While E. mandarina is distributed primarily in Japan, E. hecabe is widely distributed in Asia, Africa, and Australia. Therefore, the robustness of this multiplex PCR needs to be confirmed by including samples from other populations in the world, particularly for E. hecabe.

\section{Supplementary information}

Supplementary information accompanies this paper at https://doi. org/10.1186/s13104-020-05093-3.

Additional file 1. Sample information used in this study.

\section{Abbreviations}

mtDNA: Mitochondrial DNA; PCR: Polymerase chain reaction; Tpi:Triose phosphate isomerase.

\section{Acknowledgements}

We would like to thank Naoto Haruyama, Ryu Osaka, Takuya Yamaji, Rie Sato, Amami Shintani, Fumiaki Saitoh, Yuta Shima, Taichi Nemoto and Ken Sahara for providing us with samples of E. mandarina.

\section{Authors' contributions}

MNM, DK and MN designed the study. MNM performed molecular experiments. MNM wrote the draft of the manuscript, which was revised by DK and MN. All authors read and approved the final manuscript.

\section{Funding}

This work was supported by Grant-in-Aid for JSPS Fellows (KAKENHI Grant Number 18J21090) to MNM and Grant-in-aid for Scientific Research (B) (KAKENHI Grant Number 19H02972) to DK.

\section{Availability of data and materials}

All data generated or analyzed during this study are included in this published article and its supplementary information file.

\section{Ethics approval and consent to participate}

Not applicable.

\section{Consent for publication}

Not applicable.

\section{Competing interests}

The authors declare that they have no competing interests.

Received: 23 February 2020 Accepted: 16 May 2020

Published online: 27 May 2020

\section{References}

1. Resh V, Cardé R. Encyclopedia of Insects. 1st ed. Cambridge: Academic Press; 2003. p. 1266

2. Butcher B, Smith M, Sharkey M, Quicke DL. A turbo-taxonomic study of Thai Aleiodes (Aleiodes) and Aleiodes (Arcaleiodes) (Hymenoptera: Braconidae: Rogadinae) based largely on COI barcoded specimens, with rapid descriptions of 179 new species. Zootaxa. 2012;3457:1-232.

3. Hebert PDN, Ratnasingham S, DeWaard JR. Barcoding animal life: Cytochrome coxidase subunit 1 divergences among closely related species. Proc R Soc B Biol Sci. 2003;270(SUPPL. 1):96-9.

4. Rubinoff D. Utility of mitochondrial DNA barcodes in species conservation. Conserv Biol. 2006:20:1026-33.

5. Hebert PDN, Cywinska A, Ball SL, DeWaard JR. Biological identifications through DNA barcodes. Proc R Soc B Biol Sci. 2003;270:313-21.

6. Ballard JWO, Whitlock MC. The incomplete natural history of mitochondria. Mol Ecol. 2004;13:729-44.

7. Ullrich KK, Linnenbrink M, Tautz D. Introgression patterns between house mouse subspecies and species reveal genomic windows of frequent exchange. BioRxiv. 2017. https://doi.org/10.1101/168328.

8. Currat M, Ruedi M, Petit RJ, Excoffier L. The hidden side of invasions: massive introgression by local genes. Evolution. 2008;62:1908-20.

9. Birky CW, Fuerst P, Maruyama T. Organelle gene diversity under migration, mutation, and drift: equilibrium expectations, approach to equilibrium, effects of heteroplasmic cells, and comparison to nuclear genes. Genetics. 1989;121:613-27.

10. Bachtrog D, Thornton K, Clark A, Andolfatto P. Extensive introgression of mitochondrial Dna relative to nuclear genes in the Drosophila yakuba species group. Evolution. 2006;60:292

11. Eberle J, Ahrens D, Mayer C, Niehuis O, Misof B. A plea for standardized nuclear markers in metazoan DNA taxonomy. Trends Ecol Evol. 2020;35:1-10.

12. Yata O. A revision of the Old World species of the genus Eurema Hübner (Lepidoptera, Pieridae) Part I. Phylogeny and zoogeography of the subgenus Terias Swainson and description of the subgenus Eurema Hübner. Bull Kitakyushu Museum Nat Hist. 1989;9:1-103.

13. Kato $Y$, Handa H. Seasonal polyphenism in a subtropical population of Eurema hecabe (Lepidoptera, Pieridae). Japanese J Entomol. 1992;60:305-18.

14. Kato Y. Host-plant adaptation in two sympatric types of the butterfly Eurema hecabe (L.) (Lepidoptera: Pieridae). Entomol Sci. 2000;3:459-63.

15. Kato Y. Fringe color, seasonal morph and host-plant use of the pierid butterfly Eurema hecabe (L.) (Lepidoptera, Pieridae) on Okinawa-jima Island. Trans Lepidopterol Soc Japan. 1999;50:111-21.

16. Matsuno H. Difference in reflection pattern against ultraviolet rays between two types of Eurema hecabe. Gekkan Mushi. 1999;338:13-5 (in Japanese) 
17. Nomura M, Kato Y. Allozyme analyses of two closely related species of Eurema Butterflies (Lepidoptera: Pieridae) that cannot be identified with mitochondrial DNA sequences. Ann Entomol Soc Am. 2018;111:73-8.

18. Narita S, Nomura M, Kato Y, Fukatsu T. Genetic structure of sibling butterfly species affected by Wolbachia infection sweep: evolutionary and biogeographical implications. Mol Ecol. 2006;15:1095-108.

19. Kato Y, Yata O. Geographic distribution and taxonomical status of two types of Eurema hecabe (L.) (Lepidoptera, Pieridae) in south-western Japan and Taiwan. Lepid Sci. 2005;56:171-83.

20. Shirouzu T. The butterflies of Japan in color. Shinagawa: Gakken Publishing; 2006.

21. Miyata M, Konagaya T, Yukuhiro K, Nomura M, Kageyama D. Wolbachia -induced meiotic drive and feminization is associated with an independent occurrence of selective mitochondrial sweep in a butterfly. Biol Lett. 2017;13:20170153.

22. Shoemaker DD, Dyer KA, Ahrens M, McAbee K, Jaenike J. Decreased diversity but increased substitution rate in host mtDNA as a consequence of Wolbachia endosymbiont infection. Genetics. 2004;168:2049-58.

23. Schuler H, Köppler K, Daxböck-Horvath S, Rasool B, Krumböck S, Schwarz $D$, et al. The hitchhiker's guide to Europe: the infection dynamics of an ongoing Wolbachia invasion and mitochondrial selective sweep in Rhagoletis cerasi. Mol Ecol. 2016;25:1595-609.

24. Hurst GDD, Jiggins FM. Problems with mitochondrial DNA as a marker in population, phylogeographic and phylogenetic studies: the effects of inherited symbionts. Proc Biol Sci. 2005;272:1525-34.
25. Kato Y. Fringe color, seasonal morph and host-plant use of the pierid butterfly Eurema hecabe (L.) (Lepidoptera, Pieridae) on Okinawa-jima Island. Transtepid Soc Japan. 1999;50:111-21.

26. Jiggins CD, Linares M, Naisbit RE, Salazar C, Yang ZH, Mallet J. Sex-linked hybrid sterility in a butterfly. Evolution. 2001;55:1631-8. https://doi. org/10.1554/0014-3820(2001)055\%5b1631:slhsia\%5d2.0.co;2.

27. Kumar S, Stecher G, Tamura K. MEGA7: molecular evolutionary genetics analysis version 7.0 for bigger datasets. Mol Biol Evol. 2016;33:1870-4.

28. Ye J, Coulouris G, Zaretskaya I, Cutcutache I, Rozen S, Madden TL. PrimerBLAST: a tool to design target-specific primers for polymerase chain reaction. BMC Bioinform. 2012;13:134

29. Notomi T, Okayama H, Masubuchi H, Yonekawa T, Watanabe K, Amino N, et al. Loop-mediated isothermal amplification of DNA. Nucleic Acids Res. 2000;28:e63. https://doi.org/10.1093/nar/28.12.e63.

30. Wiegmann BM, Trautwein MD, Kim JW, Cassel BK, Bertone MA, Winterton $\mathrm{SL}$, et al. Single-copy nuclear genes resolve the phylogeny of the holometabolous insects. BMC Biol. 2009;7:1-16.

\section{Publisher's Note}

Springer Nature remains neutral with regard to jurisdictional claims in published maps and institutional affiliations.
Ready to submit your research? Choose BMC and benefit from:

- fast, convenient online submission

- thorough peer review by experienced researchers in your field

- rapid publication on acceptance

- support for research data, including large and complex data types

- gold Open Access which fosters wider collaboration and increased citations

- maximum visibility for your research: over 100M website views per year

At BMC, research is always in progress.

Learn more biomedcentral.com/submissions 